\title{
Phenotypic characterisation of alveolar macrophages and peripheral blood monocytes in COPD
}

\author{
A.R. Pons*, A. Noguera*, D. Blanquer*, J. Sauleda*, J. Pons ${ }^{\#}$ and A.G.N. Agustí*
}

ABSTRACT: Alveolar macrophages (AM) participate actively in the inflammatory response that characterises chronic obstructive pulmonary disease (COPD). The present study investigated potential changes in AM phenotypes in patients with COPD.

Using flow cytometry, the surface expression of receptors implicated in phagocytosis (CD44, CD36, CD51, CD61, CD14), antigen-presenting capacity (human leukocyte antigen (HLA)-DR), costimulatory molecules (CD80, CD86, CD40) and complement receptor type 3 were assessed in AM from 18 patients with COPD, 14 smokers with normal lung function and nine nonsmokers.

When compared to smokers with normal lung function and nonsmokers, the surface expression of HLA-DR and CD80 was lower in AM of patients with COPD. In addition, these patients had a higher percentage of AM with a low level surface expression of CD44. There did not appear to be any difference in the other receptors studied in AM between the three groups. The expression of all these receptors in peripheral blood monocytes also did not differ between groups.

In conclusion, these observations suggest that the cell-mediated immune function of alveolar macrophages can be reduced in chronic obstructive pulmonary disease, and that this is a local rather than a systemic event.

KEYWORDS: CD44, CD80, chronic bronchitis, emphysema, human leukocyte antigen-DR

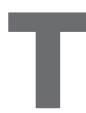
obacco smoking is the main risk factor for chronic obstructive pulmonary disease (COPD). [1]. Yet, for reasons still not fully understood, only a percentage of smokers develop COPD. Given that an abnormal inflammatory response to smoking is a hallmark of COPD [1], it is plausible that differences in the mechanisms that control the initiation and/or resolution of this inflammatory response may explain the susceptibility to develop COPD exhibited by some smokers [2].

Alveolar macrophages (AM) play a key role in both the initiation and resolution of the inflammatory response in the lower human respiratory tract [3]. AM have the ability to change their surface phenotype [4,5] and functional properties in response to exogenous stimuli and/or pathological processes in the lung parenchyma $[6,7]$. Some surface receptors associated with host defence and inflammation act as good markers of macrophage functional activation and can be modified by different inflammatory signals occurring in a variety of lung diseases, including sarcoidosis [8], pulmonary fibrosis [7], allergic airway inflammation $[9,10]$, and pulmonary tuberculosis [6]. Examples of these receptors are those implicated in phagocytosis (CD44, CD36, CD51, CD61, CD14), antigen-presenting capacity (human leukocyte antigen (HLA)-DR), or several costimulatory molecules (CD80, CD86, CD40) or complement receptor type 3 (CD11b).

Increasing evidence implicates AM in the inflammatory response that characterises COPD [11, 12]. In patients with COPD, AM release more matrix metalloproteinase-9 [13] and interleukin-8 [14], and less tissue inhibitor of metalloproteinase$1[13,15]$ and transforming growth factor- $\beta 1$ [15] than healthy smokers, and also have a limited ability to phagocytose apoptotic cells [16]. Yet, to date their surface phenotype has not been characterised although several previous studies have investigated the influence of tobacco smoking upon AM surface phenotype [17-24].

To get a better insight into the inflammatory response of COPD, the present study sought to compare the pattern of cell surface receptor expression of AM in patients with COPD, smokers with normal lung function and nonsmokers. Peripheral blood monocytes (PBM) are the circulating precursors of AM [25]. To ascertain whether potential differences of AM

\section{AFFILIATIONS}

*Serveis de Analisis Clinics, Pneumologia, and \#Immunology, Hospital Universitari Son Dureta, Institut Universitari de Investigacións en Ciències de la Salut (IUNICS), Palma de Mallorca, Spain.

CORRESPONDENCE

A. Noguera

Servei de Analisis Clinics

Hospital Universitari Son Dureta

Andrea Doria 55

07014 Palma Mallorca

Spain

Fax: 34971175749

E-mail: anoguera@hsd.es

Received

May 272004

Accepted after revision:

December 032004

SUPPORT STATEMENT

This study was supported, in part, by CYCIT (SAF 2001/0203) and Red Respira (RTIC 03/11, Fondo de Investigación Sanitaria, Instituto de Salud Carlos III) grants from the Spanish Ministry of Health. SEPAR (Sociedad Española de Patología del Aparato Respratorio), the main Spanish medical society of respiratory pathology, and the respiratory medical foundation ABEMAR (Associació Balear per l'Estudi de les Malaties de l'Aparell Respiratori). 
phenotype could also be determined in the systemic circulation, the pattern of surface receptor expression of PBM in the same individuals was studied. This may help to separate the effects derived from changes in the local pulmonary microenvironment (expected to induce phenotypic differences in AM only), from those that may potentially reflect a different genetic background (expected to induce phenotypic variance in both AM and PBM).

\section{METHODS}

\section{Subjects and ethics}

In total the following patients were recruited from the outpatient clinic of the Hospital Universitari Son Dureta, Palma de Mallorca, Spain: 18 patients with COPD (seven current smokers, 11 ex-smokers), as defined by Global Institute for Chronic Obstructive Lung Disease (GOLD) criteria (forced expiratory volume in one second (FEV1) $<70 \%$ predicted) [1]; 14 smokers (seven current smokers, seven ex-smokers) without chronic bronchitis or dyspnoea and with normal lung function (FEV1 $>80 \%$ pred) [1]; and nine nonsmokers. All required bronchoscopic evaluation of a solitary pulmonary nodule or haemoptysis. All subjects were free of any significant disease, including asthma, acute respiratory tract infections, bronchiectasis, interstitial lung diseases, and cardiac, hepatic or renal failure. All patients with COPD were clinically stable and had not experienced any exacerbations for $\geqslant 3$ months preceding inclusion in the study. All were treated with inhaled bronchodilators. Four patients were treated with inhaled steroids, but none received oral steroids. Smokers and nonsmokers were unmedicated. Current and ex-smokers had a smoking history of $>20$ pack-yrs. Ex-smokers with normal lung function stopped smoking $>3$ months previously. Current smokers refrained from smoking for $12 \mathrm{~h}$ before bronchoscopy. All participants signed an informed consent. The ethics committee of Hospital Universitari Son Dureta (Palma de Mallorca, Spain) approved the study protocol.

\section{Bronchoscopy}

Fibreoptic bronchoscopy and bronchoalveolar lavage (BAL) were performed according to standard techniques [26]. To investigate the presence of airways colonisation, which can potentially influence the results of the study, bronchial secretions were obtained using a protected specimen brush [27] and were found to be culture negative in all cases. Likewise, to avoid the potential effect of acute smoking, current smokers refrained from smoking for $12 \mathrm{~h}$ before bronchoscopy. This was confirmed by an exhaled $\mathrm{CO}$ concentration $<10 \mathrm{ppb}$ in all cases.

\section{Preparation of cell suspensions}

BAL samples were processed under sterile conditions within $1 \mathrm{~h}$ of collection and maintained at $4^{\circ} \mathrm{C}$ until analysis. Cells were recovered from BAL fluid by centrifugation $(400 \times g$ for $10 \mathrm{~min}$ at $4^{\circ} \mathrm{C}$ ), and suspended at a concentration of $1 \times 10^{6}$ cells $\cdot \mathrm{mL}^{-1}$ in RPMI-1640 medium containing $10 \%$ foetal calf serum, $2 \mathrm{mM}$ L-glutamine, $25 \mathrm{U} \cdot \mathrm{mL}^{-1}$ penicillin and $25 \mu \mathrm{g} \cdot \mathrm{mL}^{-1}$ streptomycin. Total cell counts were determined in a haemocytometer by light microscopy. Cell viability, as determined by trypan blue exclusion, was always $>96 \%$. Differential cell counts were performed by counting 500 cells on cytocentrifuge slides (Cytospin 2; Shandon Southern Prod.,
Ltd, Runcorn, UK) stained with Haemacolor (Merck KgaA, Darmstadt, Germany).

Blood samples were obtained by puncture of a peripheral vein. Ficoll-Hypaque gradient centrifugation (Pharmacia, Upsala, Sweden) was used to separate peripheral blood mononuclear cells, which were washed twice and suspended at a concentration of $1 \times 10^{6}$ cells $\cdot \mathrm{mL}^{-1}$ in RPMI-1640 medium containing $10 \%$ foetal calf serum, $2 \mathrm{mM}$ L-glutamine, $25 \mathrm{U} \cdot \mathrm{mL}^{-1}$ penicillin and $25 \mu \mathrm{g} \cdot \mathrm{mL}^{-1}$ streptomycin.

Inmunofluorescence labelling and flow cytometric analysis $\mathrm{AM}$ and peripheral blood mononuclear cells were labelled according to the same protocol within $1 \mathrm{~h}$ of sampling. Of the cell suspensions $\left(1 \times 10^{6}\right.$ cells $\left.\cdot \mathrm{mL}^{-1}\right), 100 \mu \mathrm{L}$ was mixed with $10 \mu \mathrm{L}$ of each FITC/Pe-labelled monoclonal antibody against the different surface receptors studied (Immunotech, Marseille, France). These included those implicated in phagocytosis (CD44: clone J.173; CD36: clone FA6.152; CD51: clone AMF7; CD61: clone SZ21; CD14: clone RM052), antigen-presenting capacity (HLA-DR: clone Immu-357), several costimulatory molecules (CD80: clone MAB 104; CD86: HA5.2B7; CD40: clone MAB89) and complement receptor type 3 (CD11b: clone Bear 1). Additionally, one $100-\mu \mathrm{L}$ aliquot of AM suspension was double labelled with CD44 and HLA-DR for further identification of AM subpopulations expressing high or low surface levels of CD44 (CD44 high ${ }^{+}$and CD44 low ${ }^{+}$, respectively). Surface expression of CD44 on AM was demonstrated by gating $\mathrm{HLA}_{-} \mathrm{DR}^{+}$cells, on which the percentages of AM expressing CD44 low ${ }^{+}$were estimated [28]. Finally, peripheral blood mononuclear cells were double labelled with $10 \mu \mathrm{L}$ of CD14 to identify PBM.

Following incubation in the dark at $4^{\circ} \mathrm{C}$ for $30 \mathrm{~min}$ and two washes in PBS, cells were re-suspended in $0.5 \mathrm{~mL}$ of PBS and analysed immediately in a flow cytometer (Coulter Epics XL.MCL; Coulter Corporation, Miami, FL, USA). AM were identified by gating on cells with high autofluorescence in the FITC channel, and typical forward and side-scatter characteristics. PBM were identified by gating on cells $\mathrm{CD} 14^{+}$. Fluorescence histograms were generated using a three-log scale and were expressed in units of mean fluorescence intensity. The immunoglobulin (Ig)-G control values for mean fluorescence intensity (FITC/Pe IgG , clone 679.1Mc7; Immunotech, Marseille, France) were subtracted from that of each specific monoclonal antibody. To generate each histogram $10,000 \mathrm{AM}$ or 5,000 PBM were analysed.

\section{Statistical analysis}

Results are presented as mean \pm SEM. Nonparametric statistics (Kruskal-Wallis test and Mann-Whitney U-test) were used to assess the statistical significance of differences between the groups. A p-value $<0.05$ was considered significant.

\section{RESULTS}

\section{Anthropometric and lung function data}

All subjects were matched for age and smoking history (table 1). No significant differences were found in results obtained in current smokers and ex-smokers. According to GOLD, patients with COPD showed moderate airflow obstruction (table 1) [1]. By definition, spirometry was normal in smokers with normal lung function and in nonsmokers. 
TABLE 1 Clinical and lung function data of all participants

\begin{tabular}{lccc} 
& Nonsmokers & \multicolumn{2}{c}{ Smokers } \\
\cline { 3 - 4 } & & Normal lung function & COPD \\
\hline Subjects $\mathbf{n}$ & 9 & 14 & 18 \\
Age yrs & $56 \pm 7$ & $60 \pm 2$ & $64 \pm 2$ \\
Pack-yrs & 0 & $36 \pm 5^{*}$ & $46 \pm 3^{*}$ \\
FEV 1 \% pred & $100 \pm 7$ & $95 \pm 3$ & $59 \pm 2^{*, \#}$ \\
FEV 1 /FVC \% & $75 \pm 2$ & $77 \pm 1$ & $57 \pm 2^{\text {*.\# }}$ \\
\hline
\end{tabular}

Data presented as mean \pm SEM, unless otherwise stated. COPD: chronic obstructive pulmonary disease; FEV 1 : forced expiratory volume in one second; FVC: forced vital capacity. ${ }^{*}: p<0.05$ versus nonsmokers; $\#$ : $p<0.05$ versus smokers with normal lung function. Spirometric reference values were taken from a Mediterranean population [29].

\section{BAL cell count}

Total cell count was higher in patients with COPD $\left(1.7 \pm 0.3 \times 10^{5} \cdot \mathrm{mL}^{-1}\right)$ and smokers with normal lung function $\left(2.3 \pm 0.4 \times 10^{5} \cdot \mathrm{mL}^{-1}\right)$ than in nonsmokers $\left(0.5 \pm 0.1 \times 10^{5} \cdot \mathrm{mL}^{-1}\right.$; $\mathrm{p}<0.05)$. Differential cell counts were not different between groups (table 2).

\section{PBM surface phenotype}

The expression of the different surface receptors studied in PBM was similar in the three subject groups (table 3 ).

\section{AM surface phenotype}

The expression of most of the surface receptors studied on AM did not differ between the three subject groups (table 3). However, the expression of HLA-DR and CD80 was lower $(\mathrm{p}<0.01)$ in patients with COPD (fig. 1). The analysis of AM subpopulations (fig. 2) showed that the percentage of AM with

\begin{tabular}{|c|c|c|c|}
\hline \multirow[t]{3}{*}{$\begin{array}{l}\text { Total and } \\
\text { bronchoal }\end{array}$} & $\begin{array}{l}\text { lifferential } \\
\text { eolar lavage }\end{array}$ & $\begin{array}{l}\text { ll counts in } \\
\text { fluid }\end{array}$ & \\
\hline & \multirow[t]{2}{*}{ Nonsmokers } & \multicolumn{2}{|c|}{ Smokers } \\
\hline & & $\begin{array}{l}\text { Normal lung } \\
\text { function }\end{array}$ & COPD \\
\hline Subjects $\mathrm{n}$ & 9 & 14 & 18 \\
\hline Total cell count $\times 10^{5} \cdot \mathrm{mL}^{-1}$ & $0.53 \pm 0.1$ & $2.32 \pm 0.4^{*}$ & $1.67 \pm 0.3^{*}$ \\
\hline \multicolumn{4}{|l|}{ Macrophages } \\
\hline$\times 10^{5} \cdot \mathrm{mL}^{-1}$ & $0.46 \pm 0.1$ & $2.1 \pm 0.4^{\star}$ & $1.5 \pm 0.2^{*}$ \\
\hline$\%$ & $86 \pm 3$ & $90 \pm 2$ & $89 \pm 1$ \\
\hline \multicolumn{4}{|l|}{ Lymphocytes } \\
\hline$\times 10^{5} \cdot \mathrm{mL}^{-1}$ & $0.06 \pm 0.01$ & $0.2 \pm 0.04$ & $0.14 \pm 0.04$ \\
\hline$\%$ & $10 \pm 3$ & $9 \pm 2$ & $8 \pm 1$ \\
\hline \multicolumn{4}{|l|}{ Neutrophils } \\
\hline$\times 10^{5} \cdot \mathrm{mL}^{-1}$ & $0.01 \pm 0.00$ & $0.02 \pm 0.00$ & $0.03 \pm 0.01$ \\
\hline$\%$ & $3.2 \pm 2$ & $0.9 \pm 0.3$ & $2.7 \pm 1$ \\
\hline
\end{tabular}

Data presented as mean \pm SEM, unless otherwise stated. COPD: chronic obstructive pulmonary disease. *: $p<0.05$ versus nonsmokers.

CD44 low $^{+}$was increased in patients with COPD $(\mathrm{p}<0.001$; fig. 3).

\section{Comparison of PBM and AM surface phenotype}

The expression of complement receptor type 3 (CD11b) and that of several receptors implicated in phagocytosis (CD36, CD61 and CD14) was higher in PBM than in AM in all groups (table 3). In contrast, the expression of costimulatory molecules (CD80, CD86 and CD40) was higher in AM, in the three groups studied. These differences reflect the process of maturation of PBM into AM [25, 30, 31].

TABLE 3 Mean fluorescence intensity values of the surface receptors studied in peripheral blood monocytes (PBM) and alveolar macrophages (AM)

\begin{tabular}{|c|c|c|c|c|c|}
\hline \multicolumn{2}{|c|}{ Nonsmokers } & \multicolumn{4}{|c|}{ Smokers } \\
\hline \multirow[b]{2}{*}{ PBM } & \multirow[b]{2}{*}{ AM } & \multicolumn{2}{|c|}{ Normal lung function } & \multicolumn{2}{|c|}{ COPD } \\
\hline & & PBM & AM & PBM & AM \\
\hline
\end{tabular}

\begin{tabular}{|c|c|c|c|c|c|c|}
\hline Subjects $n$ & & & & & & \\
\hline CD36 & $1528 \pm 237^{\# \#}$ & $13 \pm 4$ & $1713 \pm 387^{\# \#}$ & $21 \pm 7$ & $1695 \pm 188^{\# \#}$ & $13 \pm 3$ \\
\hline CD51 & $23 \pm 8$ & $18 \pm 3$ & $26 \pm 13$ & $22 \pm 3$ & $16 \pm 6$ & $18 \pm 3$ \\
\hline CD61 & $89 \pm 12^{\# \#}$ & $8 \pm 2$ & $231 \pm 59^{\# \#}$ & $16 \pm 3$ & $119 \pm 31^{\# \#}$ & $10 \pm 2$ \\
\hline CD14 & $474 \pm 21 \# \#$ & $36 \pm 7$ & $544 \pm 37^{\# \#}$ & $50 \pm 17$ & $502 \pm 33^{\# \#}$ & $25 \pm 6$ \\
\hline CD44 & $1286 \pm 41$ & $1371 \pm 102$ & $1151 \pm 59$ & $1305 \pm 48$ & $1165 \pm 42$ & $1199 \pm 74$ \\
\hline HLA-DR & $35 \pm 4$ & $46 \pm 5$ & $37 \pm 7$ & $44 \pm 4$ & $29 \pm 3$ & $28 \pm 2^{\star \star}$ \\
\hline CD80 & $1.2 \pm 0.7^{\# \#}$ & $39 \pm 4$ & $1 \pm 0.1 \# \#$ & $38 \pm 6$ & $1 \pm 0.2^{\# \#}$ & $19 \pm 4^{\star \star}$ \\
\hline CD86 & $29 \pm 3^{\# \#}$ & $248 \pm 16$ & $28 \pm 4^{\# \#}$ & $253 \pm 14$ & $25 \pm 2^{\# \#}$ & $220 \pm 19$ \\
\hline CD40 & $13 \pm 2^{\# \#}$ & $305 \pm 26$ & $21 \pm 6^{\# \#}$ & $326 \pm 27$ & $21 \pm 4^{\# \#}$ & $291 \pm 28$ \\
\hline CD11b & $685 \pm 49^{\# \#}$ & $39 \pm 9$ & $731 \pm 44^{\# \#}$ & $52 \pm 6$ & $719 \pm 38^{\# \#}$ & $49 \pm 6$ \\
\hline
\end{tabular}

Data presented as mean \pm SEM. COPD: chronic obstructive pulmonary disease; HLA: human leukocyte antigen. **: $p<0.01$ with respect to nonsmokers and smokers with normal lung function; \#\#: $p<0.01$ within groups (PBM versus AM). 

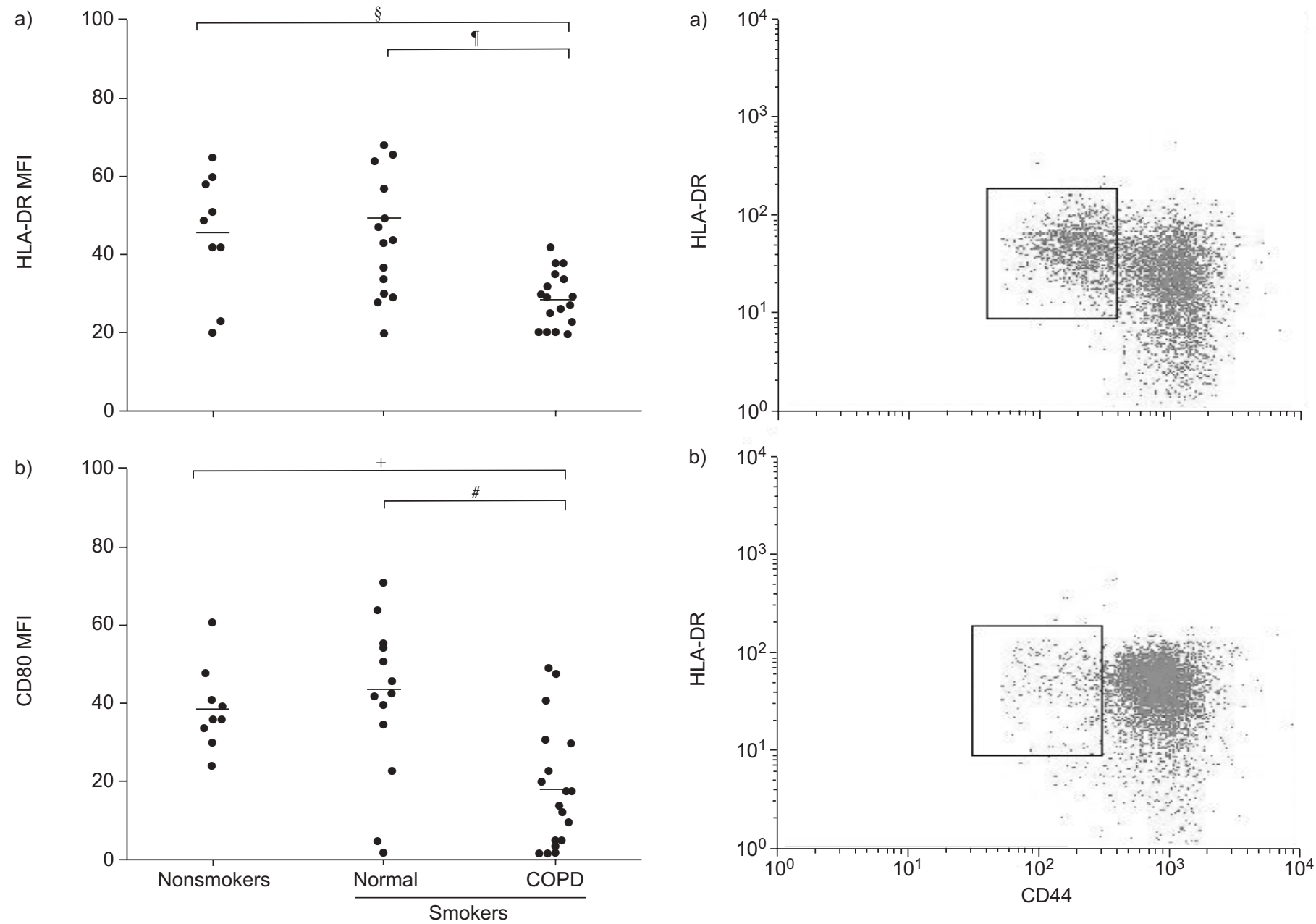

FIGURE 1. Surface expression of a) human leukocyte antigen (HLA)-DR and b) CD80 in alveolar macrophages obtained from healthy nonsmokers, smokers with normal lung function and patients with chronic obstructive pulmonary disease (COPD). \#: $p<0.02 ;{ }^{\bullet}: p=0.002 ;^{+}: p=0.003 ;{ }^{s}: p=0.006$.

\section{DISCUSSION}

Normal PBM migrate to the lungs and mature into AM [25]. $\mathrm{AM}$ are the major immunocompetent cell population in the lower human respiratory tract, and are likely to play a key role in the initiation, modulation and eventual termination of the inflammatory response that characterises COPD [32]. The different functional states of AM are mirrored by the expression of different receptors on their surface, including those implicated in phagocytosis (CD44, CD36, CD51, CD61, CD14), antigen-presenting capacity (HLA-DR), several costimulatory molecules (CD80, CD86, CD40) and complement receptor type $3(\mathrm{CD} 11 \mathrm{~b})$. The current authors hypothesised that, compared with smokers with normal lung function and nonsmokers, AM in patients with COPD may present a specific surface phenotype, which may eventually contribute to an enhanced response to tobacco smoking and/or to limit the ability to stop the response once the insult has disappeared. To explore this hypothesis, the surface phenotype of AM (and PBM) was compared in these three groups of individuals. It was found that the surface expression of the majority of receptors studied was similar in all three groups. However,

FIGURE 2. Representative characterisation of alveolar macrophages (AM) in bronchoalveolar fluid from patients with a) chronic obstructive pulmonary disease and b) smokers with normal lung function. Dual expression of CD44 and human leukocyte antigen (HLA)-DR were analysed by two-colour flow cytometry; squares indicate AM expressing low levels of CD44.

there were some notable exceptions. First, the expression of HLA-DR and CD80 on AM was reduced in patients with COPD and, secondly, the subpopulation of AM expressing CD44 low ${ }^{+}$was enhanced in the same patients.

Macrophages function as antigen-presenting cells and thereby orchestrate the activation of different subsets of lymphocytes. HLA-DR regulates antigen presentation by AM, and their expression on the surface of monocytes/macrophages is strongly related to the activation state of these cells [10]. Hence, reduced expression of HLA-DR on AM is linked with a hypo-activation state [33] and may promote immune tolerance $[34,35]$. Moreover, CD80 plays an important role in providing costimulatory signals required for the development of antigenspecific immune responses [36]. Thus, the reduced expression of HLA-DR and CD80 found in AM of COPD patients suggests that the cell-mediated immune function of AM may be abnormal in these patients. This may favour bronchial colonisation by interfering with the recognition of the antigen complex on the surface of AM by CD4+ T-helper lymphocytes 


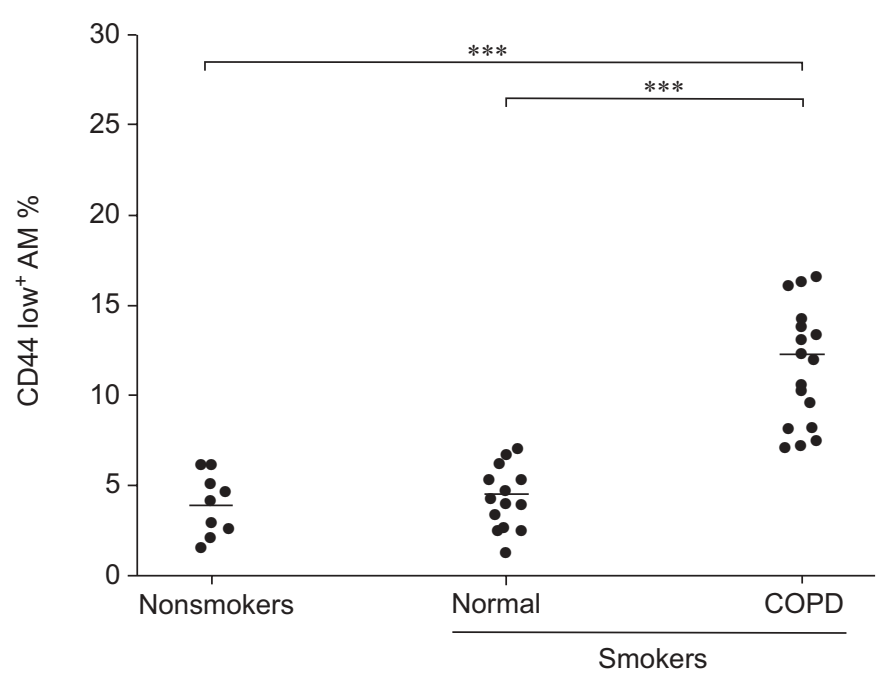

FIGURE 3. Percentage of alveolar macrophages expressing low levels of CD44 (CD44 low ${ }^{+}$) in nonsmokers, smokers with normal lung function and patients with chronic obstructive pulmonary disease (COPD). ${ }^{* \star}: p<0.001$.

[37]. The fact that the expression of HLA-DR and CD80 on PBM was similar in the three groups of subjects studied suggests that the different phenotypes observed in AM occur in response to changes in the local pulmonary milieu and rules out the possibility of a different genetic background in these patients.

CD44 is a transmembrane adhesion receptor and the major cell surface receptor for the glycosaminoglycan hyaluronan [38]. As such, CD44 plays an important role in the clearance of hyaluronan, which accumulates at sites of inflammation and tissue injury, and has pro-inflammatory functions [39]. In the normal lung, AM are the major cell type known to internalise hyaluronan for degradation, and CD44 participates in this process [40]. Moreover, CD44 ligation on macrophages selectively promotes the uptake of apoptotic neutrophils in vitro [41]. Therefore, overall CD44 plays a major role in the resolution of lung inflammation [42]. The current study found that the percentage of AM expressing CD44 low ${ }^{+}$was higher in patients with COPD than in smokers with normal lung function and nonsmokers. This may determine a decreased hyaluronan-binding capacity [28] and, therefore, limit the ability of AM in patients with COPD to clear apoptotic neutrophils [41-43], and contribute to perpetuate lung inflammation. Yet, because of the the cross-sectional design of the current study, it cannot be established whether these alterations are involved in the primary pathogenesis of the disease or are a consequence of it.

In conclusion, the current study shows that the alveolar macrophages in patients with chronic obstructive pulmonary disease exhibit a specific surface phenotype, characterised by reduced expression of two receptors involved in antigen presentation (human leukocyte antigen-DR and CD80) and one receptor involved in the termination of the inflammatory response (CD44). These observations highlight two previously undescribed alterations that may contribute to the abnormal inflammatory response that characterises chronic obstructive pulmonary disease.

\section{ACKNOWLEDGEMENTS}

The authors would like to thank the participating individuals for their collaboration in the study; and F. Bauzà, M. Bosch, A. Noguera and M. López for their help during the study.

\section{REFERENCES}

1 Pauwels RA, Buist AS, Calverley PMA, Jenkins CR, Hurd S, on behalf of the GOLD scientific committee. Global strategy for the diagnosis, management and prevention of chronic obstructive pulmonary disease. NHLBI/WHO Global Initiative for Chronic Obstructive Lung Disease (GOLD) workshop summary. Am J Respir Crit Care Med 2001; 163: 1256-1276.

2 Agusti A, MacNee W, Donaldson K, Cosio M. Hypothesis: does COPD have an autoimmune component? Thorax 2003; 58: 832-834.

3 Nathan C. Points of control in inflammation. Nature 2002; 420: 846-852.

4 Spiteri MA, Clarke SW, Polter LW. Isolation of phenotypically and functionally distinct macrophage subpopulations from human bronchoalveolar lavage. Eur Respir J 1992; 5: 717-726.

5 Barbosa IL, Gant VA, Hamblin AS. Alveolar macrophages from patients with bronchogenic carcinoma and sarcoidosis similarly express monocyte antigens. Clin Exp Immunol 1991; 86: 173-178.

6 Somoskovi A, Zissel G, Ziegenhagen MW, Schlaak M, Muller-Quernheim J. Accessory function and costimulatory molecule expression of alveolar macrophages in patients with pulmonary tuberculosis. Immunobiology 2000; 201: 450-460.

7 Taylor ML, Noble PW, White B, Wise R, Liu MC, Bochner BS. Extensive surface phenotyping of alveolar macrophages in interstitial lung disease. Clin Immunol 2000; 94: 33-41.

8 Striz I, Wang YM, Kalaycioglu O, Costabel U. Expression of alveolar macrophage adhesion molecules in pulmonary sarcoidosis. Chest 1992; 102: 882-886.

9 Viksman MY, Bochner BS, Stokes Peebles R, Schleimer RP, Liu PP. Expression of activation markers on alveolar macrophages in allergic asthmatics after endobronchial or whole-lung allergen challenge. Clin Immunol 2002; 104: 77-85.

10 Viksman MY, Liu MC, Bickel CA, Schleimer RP, Bochner BS. Phenotypic analysis of alveolar macrophages and monocytes in allergic airway inflammation. Am J Respir Crit Care Med 1997; 155: 858-863.

11 Keatings VM, Evans DJ, O'Connor BJ, Barnes PJ. Cellular profiles in asthmatic airways: a comparison of induced sputum, bronchial washings, and bronchoalveolar lavage fluid. Thorax 1997; 52: 372-374.

12 O'Shaughnessy TC, Ansari TW, Barnes NC, Jeffery PK. Inflammation in bronchial biopsies of subjects with chronic bronchitis: inverse relationship of CD8+ T lymphocytes with FEV1. Am J Respir Crit Care Med 1997; 155: 852-857.

13 Russell RE, Culpitt SV, DeMatos C, et al. Release and activity of matrix metalloproteinase- 9 and tissue inhibitor of metalloproteinase- 1 by alveolar macrophages from patients with chronic obstructive pulmonary disease. Am J Respir Cell Mol Biol 2002; 26: 602-609. 
14 Culpitt SV, Rogers DF, Shah P, et al. Impaired inhibition by dexamethasone of cytokine release by alveolar macrophages from patients with chronic obstructive pulmonary disease. Am J Respir Crit Care Med 2003; 167: 24-31.

15 Sauleda J, Pons AR, Pons J, et al. Patients with chronic obstructive pulmonary disease showed decreased release of TIMP-1 and TGF- in cultured alveolar macrophages. Am J Respir Crit Care Med 2003; 167: A871.

16 Hodge S, Hodge G, Scicchitano R, Reynolds PN, Holmes M. Alveolar macrophages from subjects with chronic obstructive pulmonary disease are deficient in their ability to phagocytose apoptotic airway epithelial cells. Immunol Cell Biol 2003; 8: 289-296.

17 Israel-Assayag E, Dakhama A, Lavigne S, Laviolette M, Cormier Y. Expression of costimulatory molecules on alveolar macrophages in hypersensitivity pneumonitis. Am J Respir Crit Care Med 1999; 159: 1830-1834.

18 Lensmar C, Elmberger G, Skold M, Eklund A. Smoking alters the phenotype of macrophages in induced sputum. Respir Med 1998; 92: 415-420.

19 Pankow W, Neumann K, Ruschoff J, Von Wichert P. Human alveolar macrophages: comparison of cell size, autofluorescence, and HLA-DR antigen expression in smokers and nonsmokers. Cancer Detect Prev 1995; 19: 268-273.

20 Khaldoyanidi S, Sikora L, Orlovskaya I, Matrosova V, Kozlov V, Sriramarao P. Correlation between nicotineinduced inhibition of hematopoiesis and decreased CD44 expression on bone marrow stromal cells. Blood 2001; 98: 303-312.

21 Hoosgsteden HC, van Hal PT, Wijkhuijs JM, Hop W, Verkaik AP, Hilvering C. Expression of the CD11/CD18 cell surface adhesion glycoprotein family on alveolar macrophages in smokers and nonsmokers. Chest 1991; 100: 1567-1571.

22 Schaberg T, Lauer C, Lode H, Fischer J, Haller H. Increased number of alveolar macrophages expressing adhesion molecules of the leukocyte adhesion molecule family in smoking subjects. Association with cell-binding ability and superoxide anion production. Am Rev Respir Dis 1992; 146: 1287-1293.

23 Striz I, Wang YM, Scarcova I, Trnka L, Sorg C, Costabel U. The phenotype of alveolar macrophages and its correlation with immune cells in bronchoalveolar lavage. Eur Respir J 1993; 6: 1287-1294.

24 Skold CM, Lundahl J, Hallden G, Hallgren M, Eklund A. Chronic smoke exposure alters the phenotype pattern and the metabolic response in human alveolar macrophages. Clin Exp Immunol 1996; 106: 108-113.

25 Andreesen R, Brugger W, Scheibenbogen C, et al. Surface phenotype analysis of human monocyte to macrophage maturation. J Leukoc Biol 1990; 47: 490-497.

26 Rennard SI, Aalbers R, Bleecker E, et al. Bronchoalveolar lavage: performance, sampling procedure, processing and assessment. Eur Respir J 1998; 11: 13-15.

27 Wimberley NW, Bass JB Jr, Boyd BW, Kirkpatrick MB, Serio RA, Pollock HM. Use of a bronchoscopic protected catheter brush for the diagnosis of pulmonary infections. Chest 1982; 81: 556-562.
28 Katoh S, Matsubara Y, Taniguchi H, et al. Characterization of CD44 expressed on alveolar macrophages in patients with diffuse panbronchiolitis. Clin Exp Immunol 2001; 126: 545-550.

29 Roca J, Sanchis J, Agustí-Vidal A, et al. Spirometric reference values for a mediterranean population. Bull Eur Physiopathol Respir 1986; 22: 217-224.

30 Prieto J, Eklund A, Patarroyo M. Regulated expression of integrins and other adhesion molecules during differentiation of monocytes into macrophages. Cell Immunol 1994; 156: 191-211.

31 Wahlstrom J, Berlin M, Sköld CM, Wigzell H, Eklund A, Grunewald J. Phenotypic analysis of lymphocytes and monocytes/macrophages in peripheral blood and bronchoalveolar lavage fluid from patients with pulmonary sarcoidosis. Thorax 1999; 54: 339-346.

32 Shapiro SD. The macrophage in chronic obstructive pulmonary disease. Am J Respir Crit Care Med 1999; 160: S29-S32.

33 Mokard D, Guery BP, Bouabdallah R, et al. Deactivation of alveolar macrophages in septic neutropenic ARDS. Chest 2003; 124: 644-652.

34 Muehlstedt SG, Lyte M, Rodriguez JL. Increased IL-10 production and HLA-DR suppression in the lungs of injured patients precede the development of nosocomial pnemonia. Shock 2002; 17: 443-450.

35 Odeberg J, Soderberg-Naucler C. Reduced expression of HLA Class II molecules and interleukin-10 and transforming growth factor $\beta 1$ - independent supression of T-cell proliferation in human cytomegalovirus-infected macrophage cultures. J Virol 2004; 75: 5174-5181.

36 Zhang P, Martin M, Yang QB, Michalek SM, Katz J. Role of B7 costimulatory molecules in immune responses and T-helper cell differentiation in response to recombinant HagB from Porphyromonas gingivalis. Infect Immun 2004; 72: 637-644.

37 Abbas A, Lichtman AH, Pober J. Effector mechanisms of cellular immnunity. In: Cellular and Molecular Immunology. Philadelphia, WB Saunders, 2000; pp. 291308.

38 Aruffo A, Stamenkovic I, Melnick M, Underhill CB, Seed B. CD44 is the principal cell surface receptor for hyaluronate. Cell 1990; 61: 1303-1313.

39 McKee CM, Penno MB, Cowman M, et al. Hyaluronan (HA) fragments induce chemokine gene expression in alveolar macrophages. The role of HA size and CD44. J Clin Invest 1996; 98: 2403-2413.

40 Underhill CB, Nguyen HA, Shizari M, Culty M. CD44 positive macrophages take up hyaluronan during lung development. Dev Biol 1993; 155: 324-336.

41 Hart SP, Dougherty GJ, Haslett C, Dransfield I. CD44 regulates phagocytosis of apoptotic neutrophil granulocytes, but not apoptotic lymphocytes, by human macrophages. J Immunol 1997; 159: 919-925.

42 Teder P, Vandivier RW, Jiang D, et al. Resolution of lung inflammation by CD44. Science 2002; 296: 155-158.

43 Noguera A, Sala E, Pons AR, Iglesias J, MacNee W, Agusti AGN. Expression of adhesion molecules during apoptosis of circulating neutrophils in chronic obstructive pulmonary disease. Chest 2004; 125: 1837-1842. 